\title{
PENGELOLAAN PEMBELAJARAN PAUD \\ DALAM MENGEMBANGKAN POTENSI ANAK USIA DINI
}

\author{
${ }^{1}$ Rozalena \& ${ }^{2}$ Muhammad Kristiawan \\ ${ }^{1}$ TK Bhayangkari Kota Palembang \\ ${ }^{2}$ Dosen Program Studi Magister Manajemen Pendidikan, Universitas PGRI Palembang \\ e-mail: muhammad.kristiawan@yahoo.co.id
}

\begin{abstract}
In realizing early childhood that can develop the potential of early childhood required the existence of planning, organizing, implementation, and controlling. This paper was library research. The result obtained indicate that PAUD learning activities consist of Teaching and Learning Activities, Reviewing the Education Calendar, and Learning Schedule Arrangements. Guidelines for learning organization are concerned on defining developmental stages, capacity indicators, defining the concept of knowledge introduced, setting themes, developing learning activities, preparing tools and materials. Learning planning strategy should pay attention to SKH (Daily Activities Unit) and SKM (Weekly Activities Unit). The curriculum should be structured by considering the differences which is appeared in society, then learners can recognize the diversity of social life. The setting of learning class is organized according to the school's vision and mission. The teacher's teaching activities start from welcoming the students in front of the school gate, carry out the learning, take the students to the front of the gate until the child is picked up by their respective parents. Early childhood learning activity is in the form of learning while dancing or moving; Drawing/coloring while learning; and memorize the word while clapping.
\end{abstract}

Keywords: Learning Organizarion; PAUD; The Potential of Early Childhood

\section{PENDAHULUAN}

PAUD berfungsi membina, menumbuhkan, dan mengembangkan seluruh potensi yang dimiliki anak pada usia dini secara optimal sehingga terbentuk perilaku dan kemampuan dasar sesuai dengan tahap perkembangannya agar memiliki kesiapan untuk memasuki pendidikan selanjutnya. Salah satu jalur terselenggaranya PAUD adalah jalur pendidikan non-formal. PAUD non-formal memiliki peran membantu pemerintah meningkatkan akses masyarakat terhadap layanan pendidikan. Oleh karena itu, pemerintah saat ini memberikan perhatian lebih terhadap PAUD terutama sarana prasarana, pembinaan tenaga pendidik dan kependidikan, dan memberikan sosialisasi pada masyarakat tentang kepedulian terhadap PAUD. Prakarsa penyelenggaraan PAUD di negara maju telah berlangsung lama sebagai bentuk pendidikan yang berbasis masyarakat, akan tetapi gerakan untuk menggalakkan pendidikan ini di Indonesia baru muncul beberapa tahun terakhir. Hal ini didasarkan akan pentingnya pendidikan untuk anak usia dini dalam menyiapkan manusia Indonesia seutuhnya, membangun masa depan anak-anak dan masyarakat Indonesia seluruhnya.

Di Indonesia, kebijakan pemerintah di sektor pendidikan yang mendukung 
pendidikan sepanjang hayat adalah diakuinya PAUD. Hal ini tertuang dalam amanah yang termuat pada pasal 28 ayat 1 UU No. 20 Tahun 2003 tentang Sistem Pendidikan Nasional. Hal ini menunjukkan bahwa secara yuridis formal, PAUD merupakan bagian yang tak terpisahkan dari keseluruhan Sistem Pendidikan Nasional. Walaupun pendidikan pra-sekolah bukan merupakan kewajiban dan prasyarat untuk memasuki Sekolah Dasar (Prapsiwi, 2012).

Dengan diberlakukannya UU No.20 Tahun 2003, PAUD menjadi bagian dari sistem pendidikan di Indonesia yang integral dan sistemik. PAUD diselenggarakan sebelum jenjang Pendidikan Dasar. PAUD dapat diselenggarakan melalui jalur pendidikan formal, non-formal atau informal. PAUD pada jalur pendidikan formal berbentuk Taman Kanak-kanak (TK), Raudatul Athfal (RA). PAUD pada jalur pendidikan non-formal berbentuk Kelompok Bermain (KB), Taman Penitipan Anak (TPA). PAUD pada jalur pendidikan informal berbentuk pendidikan keluarga dan yang diselenggarakan oleh lingkungan masyarakat. Oleh karena itu, PAUD menjadi sangat penting mengingat potensi kecerdasan dan dasar-dasar perilaku seseorang terbentuk pada rentang usia ini.

Generasi yang berkualitas adalah harapan masyarakat, masyarakat sangat mengharapkan adanya pendidikan yang memadai untuk putra putrinya, terlebih pada saat mereka masih berada dalam usia dini. Pentingnya PAUD telah menjadi perhatian Internasional. Dalam pertemuan forum pendidikan tahun 2000 di Dakar Sinegal, salah satu butir kesepakatannya adalah memperluas dan memperbaiki keseluruhan perawatan dan PAUD, terutama bagi mereka yang sangat rawan dan kurang beruntung (Noorlaila, 2010: 14).

Sedemikian pentingnya masa ini sehingga usia dini sering disebut sebagai The Golden Age (usia emas). Golden Age merupakan suatu masa keemasan anak usia dini antara 0-6 tahun, di mana anak harus diberikan pendidikan, stimulus dan contoh kongkrit dari berbagai pihak dan lingkungannya dalam rangka melaui tahapan tahapan perkembangannya termasuk perkembangan otak dan kecerdasannya. Anak Usia Dini yang sudah dapat sekolah baik di PAUD formal maupun informal dalam perkembangan kemampuan dan kecerdasannya dibantu oleh guru. Sebagai tenaga profesional, guru harus memiliki kompetensi pedagogi dan profesional. Lebih khusus lagi pengelolaan pembelajaran yang dapat mengoptimalkan kecerdasan personal anak (Kusbudiah, 2014).

Dalam mewujudkan PAUD yang dapat mengembangkan potensi anak usia dini diperlukan adanya Planning (perencanaan), Organizing (pengorganisasian), Actuating (pelaksanaan), dan juga Controlling 
(pengendalian) yang kemudian disingkat dengan POAC. Tanpa adanya POAC, maka pembelajaran PAUD tidak akan berjalan secara efektif dan efisien dalam mencapai tujuan.

Menurut hasil penelitian di bidang neurologi, pada usia 4 tahun pertama separuh kapasitas kecerdasan manusia sudah terbentuk. Artinya kalau pada usia tersebut otak anak tidak mendapatkan rangsangan yang maksimal, maka potensi otak anak tidak akan berkembang secara optimal. Sampai usia 8 tahun, $80 \%$ kapasitas kecerdasan manusia sudah terbentuk, artinya kapasitas kecerdasan anak hanya bertambah $30 \%$ setelah usia 4 tahun hingga mencapai usia 8 tahun. Selajutnya kapasitas kecerdasan anak tersebut akan mencapai $100 \%$ setelah berusia sekitar 18 tahun (Prapsiwi, 2012).

Adanya karakteristik khusus pada anak usia dini maka pendidikan untuk anak usia dini juga dilakukan dengan cara yang spesifik pula. PAUD atau Early Childhood Care and Education (ECCE) mempunyai potensi untuk mengembangkan ketrampilan sosial, bahasa dan komunikasi serta keterampilan motorik pada anak-anak usia dini. Hal ini dapat dilakukan apabila lingkungan pendidikan dapat memacu imajinasi mereka dan lingkungan pendidikan menyenangkan bagi mereka (Poerwanti, 2017).

\section{METODE PENELITIAN}

Artikel ini menggunakan pendekatan library research atau penelitian kepustakaan. Penelitian Kepustakaan merupakan jenis penelitian kualitatif yang pada umumnya tidak terjun ke lapangan dalam pencarian sumber datanya. Penelitian Kepustakaan merupakan metode yang digunakan dalam pencarian data, atau cara pengamatan (bentuk observasi) secara mendalam terhadap tema yang diteliti untuk menemukan 'jawaban sementara' dari masalah yang ditemukan di awal sebelum penelitian ditindaklanjuti. Dengan kata lain Penelitian kepustakaan merupakan metode dalam pencarian, mengumpulkan dan menganalisi sumber data untuk diolah dan disajikan dalam bentuk laporan Penelitian Kepustakaan. Menurut Muhadjir (1996:169), penelitian kepustakaan itu lebih memerlukan olahan filosofis dan teoritis daripada uji empiris di lapangan. Karena sifatnya teoritis dan filosofis, penelitian kepustakaan sering menggunakan pendekatan filosofis (philosophical approach) daripada pendekatan yang lain. Metode penelitiannya mencakup sumber data, pengumpulan data, dan analisis data.

\section{HASIL PENELITIAN DAN \\ PEMBAHASAN}

Sistem pengelolaan pembelajaran PAUD meliputi Kegiatan Belajar Mengajar, Menelaah Kalender Pendidikan, dan 
Pengaturan Jadwal Pembelajaran. Ketiga hal tersebut merupakan hal hal yang saling berkaitan dan tidak dapat berdiri sendiri karena akan berpengaruh pada perencanaan, pelasanaan dan evaluasi pembelajaran di kelas.

Pengelolaan pembelajaran di tingkat manapun memiliki fungsi untuk memudahkan pengelolanya dalam mencapai tujuan pendidikan baik secara umum yang tertuang dalam peraturan pemerintah atau undangundang pendidikan yang berlaku. Artinya dalam melaksanakan pengelolaan pembelajaran diperlukan perencanaan yang baik, pelaksanaan pembelajaran yang sesuai dengan rencana dan pengawasan yang diwujudkan dengan sistem penilaian yang obyektif, jujur, dan menurut standar penilaian yang ditetapkan sebelumnya.

Dalam acuan menu pembelajaran PAUD disebutkan bahwa pedoman penyelenggaraan pembelajaran meliputi penyusunan rencana kegiatan yang akan dilakukan selama satu tahun. Kegiatan tersebut berkaitan dengan menetapkan tahap perkembangan, indikator kemampuan, menetapkan konsep pengetahuan yang akan dikenalkan, menetapkan tema, menyusun rencana kegiatan pembelajaran, menyiapkan alat dan bahan.

Pada tahap pertama, pihak sekolah harus menetapkan tahap perkembangan peserta didik. Pihak pengelola harus memahami perkembangan kelompok anak yang akan mereka bina. Hal itu dikarenakan anak usia dini memiliki karakteristik yang khas, baik secara phisik, psikis, soaial, moral dan sebagainya. Masa kanak-kanak adalah masa pembentukan pondasi dan kepribadian yang akan menentukan pengalaman anak selanjutnya. Sebegitu pentingnya pada usia ini, maka memahami karakteristik usia dini menjadi mutlak adanya bila ingin memiliki generasi yang mampu mengembangkan diri secara optimal.

Tahap kedua adalah menentukan indikator kemampuan. Dalam indikator kemampuan para siswa akan diukur kemampuannya di aspek tertentu. Pengukuran tersebut dibuat rencana pembelajaran yang akan dilaksanakan untuk satu minggu atau lebih tergantung pada pencapain kemampuan anak. Oleh karena itu dibutuhkan adanya Rencana Kegiatan Harian (RKH) dan juga Rencana Kegiatan Mingguan (RKM). Tujuannya agar kegiatan pembelajaran yang akan dilaksanakan dapat terlaksana dengan baik dan juga dapat diperoleh hasil yang maksimal.

Untuk tahap ketiga, guru harus menetapkan konsep pengetahuan yang akan dikenalkan. Konsep pengetahuan berisi tentang materi kegiatan yang akan diajarkan. Isi konsep pengetuahuan harus disesuaikan dengan tujuan dari lembaga yang bersangkutan. Metode belajar sambil bermain 
memang tepat diterapkan di PAUD karena bermain merupakan dunia anak dan media balajar yang baik untuk anak. Dan untuk metode pembelajaran yang digunakan harus sinergis dengan strategi belajar sambil bermain atau bermain sambil belajar yang dikenal dengan nama Beyond Center and Circle Time (BCCT). Konsep belajar yang diterapkan dalam metode BCCT menghadirkan dunia nyata di dalam kelas dan mendorong anak didik membuat hubungan antara pengetahuan, pengalaman dan penerapan dalam kehidupan mereka sehari-hari. Sehingga otak anak dirangsang untuk terus berpikir secara aktif dalam menggali pengalamannya sendiri bukan sekedar mencontoh dan menghafal saja.

Tahap keempat adalah tenaga pengajar menetapkan tema pembelajaran yang akan diajarkan. Tema yang diajarkan dapat berkaitan dengan 8 sentra yaitu sentra seni, persiapan, imtag, memasak, bahan alam dan sains, main peran (drama), balok dan smot. Untuk setiap sentra diajarkan rata-rata selama tiga minggu. Sehingga dibutuhkan waktu selama tiga kali pertemuan untuk setiap sentranya.

Terakhir adalah tahap kelima yaitu menyiapkan alat dan bahan. Sarana dan prasarana yang harus dimiliki sekolah yaitu sarana permainan dalam ruangan (indoor) antara lain 4 unit balok, 3 unit lego (set), 3 boneka, 12 papan jahit, 36 puzzle, 3 gunting, dan 3 lusin krayon atau pensil warna dan mainan di luar ruangan (outdoor) antara lain 2 buah ayunan, 2 perosotan dan 2 jungkitan. PAUD sebaiknya memiliki gedung sendiri juga, yang terdapat beberapa ruang kelas, ruang kepala sekolah dan guru, perpustakaan, mushola serta ruang untuk bermain siswa.

Selanjutnya, dilakukan evaluasi pembelajaran. Kegiatan evaluasi pembelajarannya mengacu pada Acuan Menu Pembelajaran Generik. Dalam menu tersebut tenaga pengajar harus melakukan penilaian menyeluruh, berkesinambungan, objektif, mendidik dan bermakna baik bagi guru, orang tua, anak didik maupun pihak lain yang memerlukan. Kegiatan evaluasi pembelajaran yang dilaksanakn terdiri dari tiga kegiatan, yaitu melalui pengamatan, catatan anekdot dan portofolio. Catatan anekdot merupakan catatan mengenai sikap dan perilaku anak dalam situasi tertentu di dalam kelas maupun di luar kelas, baik yang bersifat positif maupun negatif. Dengan catatan anekdot ini guru dapat mengetahui dan mengembangkan cara menyesuaikan diri dengan kebutuhan dan kesulitan yang dihadapi anak dalam kegiatan belajarnya.

Adapun Implikasinya (1) jika persiapan penyelenggaraan atau strategi perencanaan pembelajaran yang dilakukan sekolah sudah sesuai dengan acuan yang ada maka dalam pelaksanaan pembelajarannya akan semakin 
mudah. (2) apabila proses pelaksanaan pembelajaran sudah sesuai dengan perencanaan yang ada maka akan diperoleh hasil yang efektif dan maksimal. (3) kalau kegiatan evaluasi pengelolaan pembelajaran terhadap siswa yang dilaksanakan secara berkelanjutan maka pihak sekolah dapat mengetahui kemampuan siswa apakah sudah memenuhi standar atau belum.

Bagi guru, kesiapan penyelenggaraan atau strategi perencanaan pembelajaran sebaiknya memperhatikan SKH (Satuan Kegiatan Harian) dan SKM (Satuan Kegiatan Mingguan). Jangan sampai yang diperhatikan hanya Satuan Kegiatan Harian (SKH) saja tetapi Satuan Kegiatan Mingguan (SKM) tidak. Dengan memperhatikan keduanya akan mempermudah dalam menyusun rencana kegiatan yang lain. Bagi pengelola, jumlah pertemuan untuk masing-masing kelas dengan frekuensi lima hari dalam seminggu sebaiknya ditambah satu hari lagi, sampai hari sabtu, walau hanya sampai jam 09.00 atau 10.00 WIB. Hal ini berhubungan dengan penanam sifat dan karakter serta kedisiplinan, agar anak tidak merasa kaget nantinya jika melanjutkan ke jenjang pendidikan yang lebih tinggi. Selain itu juga diperlukan adanya kegiatan pertemuan dengan orang tua siswa secara periodik agar terjalin hubungan yang baik antara guru dengan orang tua dalam menyelaraskan persepsi tentang perkembangan anak.
Pengembangan kurikulum PAUD harus didasarkan pada beberapa prinsip yaitu 1) bersifat komprehensif; 2) dikembangkan atas dasar perkembangan secara bertahap; 3) melibatkan orang tua; 4) melayani kebutuhan individu anak; 5) merefleksikan kebutuhan dan nilai masyarakat; 6) mengembangkan standar kompetensi anak; 7) mewadahi layanan anak berkebutuhan khusus; 8) menjalin kemitraan dengan keluarga dan masyarakat; 9) memperhatikan kesehatan dan keselamatan anak; 10) menjabarkan prosedur pengelolaan Lembaga; 11) manajemen Sumber Daya Manusia; dan 12) penyediaan Sarana dan Prasarana. Hasil penelitian yang dilakukan oleh Meyer (2010) "Diversity in Early Childhood Education" menunjukkan bahwa beragamnya kondisi sosial kemasyarakatan sangat mempengaruhi dalam penyusunan kurikulum PAUD. Kurikulum harus disusun dengan mempertimbangkan adanya berbagai perbedaan yang ada di dalam masyarakat sehingga peserta didik dapat mengenali adanya keragaman dalam kehidupan bermasyarakat.

Struktur kurikulum mencakup pengembangan potensi peserta didik baik psikis maupun fisik. Aspek-aspek yang di kembangkan terdiri dari moral dan nilai-nilai agama, sosial emosional, kognitif, bahasa, motorik, kemandirian dan seni agar peserta didik siap untuk memasuki pendidikan dasar. Hal ini sesuai dengan hakekat PAUD sesuai 
pendapat Kelloguh, bahwa pembelajaran PAUD pada hakikatnya adalah pembelajaran yang berorientasi bermain (belajar sambil bermain dan bermain sambil belajar), pembelajaran yang berorientasi perkembangan yang lebih banyak memberi kesempatan kepada anak untuk dapat belajar dengan caracara yang tepat (Casper \& Theilheimer, 2009: 12).

Bidang pengembangan yang dikembangkan dalam kurikulum tersebut meliputi dua bidang, yaitu pengembangan kebiasaan dan kemampuan dasar. Bidang pengembangan pembiasaan mencakup aspek perkembangan nilai-nilai agama dan moral serta aspek perkembangan sosial emosional. Bidang pengembangan kemampuan dasar mencakup pengembangan kemampuan motorik, kognitif, dan berbahasa. Hal ini sesuai dengan standar kompetensi anak usia dini yang meliputi aspek-aspek 1) moral dan nilai-nilai agama; 2) sosial, emosional, dan kemandirian; 3) bahasa; 4) kognitif; 5) motorik; dan 6) seni (Depdiknas, 2008: 17).

Kurikulum PAUD harus dikembangkan berdasarkan jaringan tema yang dijabarkan ke dalam program tahunan, program semester, program mingguan, dan program harian. Tema-tema yang dikembangkan berbeda antara semester I dan semester II. Pengembangan kurikulum ke dalam jaringan tema tersebut mengandung implikasi bahwa pembelajaran anak usia dini harus senantiasa berorientasi kepada kebutuhan anak. Pendidikan tersebut, menurut Klogh dan Slentz (2011: 74) harus diupayakan untuk mencapai optimalisasi semua aspek perkembangan baik perkembangan fisik maupun psikis, yaitu intelektual, bahasa, motorik, dan sosio emosional.

Menurut hasil penelitian yang dilakukan UNESCO (2007) PAUD sangat berpengaruh terhadap perkembangan kognitif, sosial, dan emosional terhadap kinerja siswa ketika mereka mengenyam pendidikan di Sekolah Dasar. Menurut temuan UNESCO bahwa "The early childhood years are critical for cognitive, social and emotional development. Early childhood education that meets the distinct needs or girls and boys can positively affect their performance in primary school and their self esteem".

Di dalam pengembangan dan penyususunan kurikulum ini di dasarkan pada beberapa prinsip, agar tujuan pendidikan dapat tercapai secara efektif dan efisien. Prinsipprinsip dalam pengembangan tersebut diantaranya adalah 1) berorientasi pada prinsip-prinsip perkembangan anak; 2) berorintasi pada kebutuhan anak; 3) bermain sambil belajar atau belajar seraya bermain; 4) menggunakan pendekatan tematik; 5) kreatif dan inovatif; 6) lingkungan kondusif; 7) mengembangkan kecakapan hidup. Struktur 
kurikulum pembelajaran melalui bermain di mana permainan yang digunakan di PAUD adalah permainan yang merangsang kreatifitas anak dan menyenangkan, pembelajaran di PAUD harus didukung dengan sarana, prasarana pembelajaran yang menarik dalam penyampaiannya seperti, pembelajaran yang disertai dengan alat peraga, permainan, macam-macam gambar dan bentuk serta harmonisasi warna yang membuat ketertarikan anak untuk belajar. Sebagaimana dikemukakan oleh Hartati (2005: 30) karakteristik PAUD meliputi 1) berangkat dari yang dimiliki anak; 2) belajar harus menantang pemahaman anak; 3) belajar dilakukan sambil bermain; 4) menggunakan alam sebagai sarana pembelajaran; 5) belajar dilakukan melalui Sensori; 6) belajar membekali ketrampilan hidup; dan 7) belajar sambil melakukan.

Setting kelas pembelajaran anak usia dini diatur sesuai dengan visi dan misi sekolah. Pengaturan tempat duduk di kelas sebaiknya diatur dengan model kelompok. Pengaturan ruangan kelas merupakan usaha yang diarahkan untuk mewujudkan suasana belajar mengajar yang efektif dan menyenangkan serta dapat memotivasi murid untuk belajar dengan baik sesuai dengan kemampuan. Dengan demikian manajemen kelas merupakan usaha sadar untuk mengatur kegiatan proses belajar mengajar secara sistematis. Usaha sadar itu mengarahkan pada penyiapan bahan belajar, penyiapan sarana dan alat peraga, pengaturan ruang belajar, pewujudan kondisi proses belajar mengajar dan pengaturan waktu sehingga pembelajaran berjalan dengan baik dan tujuan kurikuler dapat dicapai.

Tujuan utama penataan lingkungan fisik kelas ialah mengarahkan kegiatan siswa dan mencegah munculnya tingkah laku siswa yang tidak diharapkan melalui penataan tempat duduk, perabot, pajangan, dan barang-barang lainnya di dalam kelas. Penataan tempat duduk adalah salah satu upaya yang dilakukan oleh guru dalam mengelola kelas. Karena pengelolaan kelas yang efektif akan menentukan hasil pembelajaran yang dicapai. Dengan penataan tempat duduk yang baik maka diharapkan akan menciptakan kondisi belajar yang kondusif, dan juga menyenangkan bagi siswa. Penataan lingkungan kelas yang tepat berpengaruh terhadap tingkat keterlibatan dan partisipasi siswa dalam proses pembelajaran. Lebih jauh, diketahui bahwa tempat duduk berpengaruh jumlah terhadap waktu yang digunakan siswa untuk menyelesaikan tugas yang diberikan (Prapsiwi, 2012).

Dikaitkan dengan pembelajaran anak usia dini yang memiliki karakteristik yang spesifik, maka pengaturan ruangan kelas harus mampu mendukung pembelajaran anak usia dini. Pengaturan tempat duduk secara 
berkelompok tersebut dimaksudkan agar anak dapat mendorong munculnya tingkah laku siswa yang diharapkan dan menghilangkan tingkah laku yang tidak diharapkan; mengembangkan hubungan interpersonal yang baik dan iklim sosio-emosional kelas yang positif; dan untuk menciptakan dan memelihara organisasi kelas yang efektif. Pengaturan ruangan kelas dapat dilakukan dengan tiga pendekatan, yaitu pendekatan modifikasi tingkah laku (behavior modification approach); pendekatan iklim sosio-emosionaI (socio emotional climate approach); dan pendekatan proses kelompok (group process approach) (Prapsiwi, 2012). Hasil penelitian Kelley, Wetzel, Padgett, Williams, dan Odom (2003: 67-83) menyimpulkan bahwa guru anak usia dini harus mampu mempersiapkan peserta didik untuk beradaptasi dengan lingkungan sehingga mereka dapat membangun pengetahuan sesuai dengan konteks yang mereka hadapi dalam kehidupan sehari-hari.

Aktivitas mengajar guru anak usia dini harus dimulai sejak 15 menit sebelum kegiatan pembelajaran dimulai dan baru berakhir setelah menyelesaikan administrasi pembelajaran setelah diakhirinya pembelajaran. Aktivitas tersebut berupa menyambut peserta didik di depan gerbang sekolah, melaksanakan pembelajaran, hingga mengantar peserta didik ke depan gerbang sampai anak tersebut dijemput oleh orang tua masing-masing. Klogh dan Slentz (2011: 74) mengungkapkan bahwa kegiatan pembelajaran pada anak usia dini harus senantiasa berorientasi kepada kebutuhan anak. Atas dasar hal tersebut, maka aktivitas guru dalam pembelajaran anak usia dini adalah harus mampu mendorong tercapainya optimalisasi semua aspek perkembangan baik perkembangan fisik maupun psikis, yaitu intelektual, bahasa, motorik, dan sosio emosional.

Aktivitas belajar anak Usia Dini bisa dimulai pada jam 07.15 sampai dengan jam 11.00 WIB. Kegiatan dimulai dengan berbaris secara rapi di depan kelas masing-masing kemudian menempatkan tas bawaan masingmasing di tempat yang sudah disediakan. Aktivitas belajar anak usia dini adalah berupa belajar sambil menari atau bergerak; menggambar/mewarnai sambil belajar; dan menghafal kata sambil bertepuk tangan. Semua aktivitas yang dilakukan tersebut merupakan aktivitas bermain sambil belajar. Klogh dan Slentz (2011: 112) menyatakan bahwa belajar pada anak usia dini adalah bermain. Melalui bermain dapat memberi kesempatan bagi anak untuk bereksplorasi, menemukan, mengekspresikan perasaan, berkreasi, dan belajar secara menyenangkan. Selain itu, bermain juga dapat membantu anak 
mengenal tentang diri sendiri, dengan siapa ia hidup, dan di lingkungan mana ia hidup.

\section{KESIMPULAN}

Sistem pengelolaan pembelajaran PAUD meliputi Kegiatan Belajar Mengajar, Menelaah Kalender Pendidikan, dan Pengaturan Jadwal Pembelajaran. Pedoman penyelenggaraan pembelajaran meliputi penyusunan rencana kegiatan yang akan dilakukan selama satu tahun. Kegiatan tersebut berkaitan dengan menetapkan tahap perkembangan, indikator kemampuan, menetapkan konsep pengetahuan yang akan dikenalkan, menetapkan tema, menyusun rencana kegiatan pembelajaran, menyiapkan alat dan bahan. Bagi guru, kesiapan penyelenggaraan atau strategi perencanaan pembelajaran sebaiknya memperhatikan SKH (Satuan Kegiatan Harian) dan SKM (Satuan Kegiatan Mingguan). Kurikulum harus disusun dengan mempertimbangkan adanya berbagai perbedaan yang ada di dalam masyarakat sehingga peserta didik dapat mengenali adanya keragaman dalam kehidupan bermasyarakat. Setting kelas pembelajaran anak usia dini diatur sesuai dengan visi dan misi sekolah. Pengaturan tempat duduk di kelas sebaiknya diatur dengan model kelompok. Aktivitas mengajar guru anak usia dini terdiri atas menyambut peserta didik di depan gerbang sekolah, melaksanakan pembelajaran, hingga mengantar peserta didik ke depan gerbang sampai anak tersebut dijemput oleh orang tua masing-masing. Aktivitas belajar anak usia dini adalah berupa belajar sambil menari atau bergerak; menggambar/mewarnai sambil belajar; dan menghafal kata sambil bertepuk tangan.

\section{DAFTAR PUSTAKA}

Bowman, Barbara T., M. Suzanne Donovan, and M. Susan Burns (editors). (2010). Eager to Learn: Educating Our Preschoolers. Washington DC: National Academy Press.

Casper, V. \& Theilheimer, R. (2009). Introduction to Early Childhood Education: Learning Together. New York: McGraw-Hill.

Depdiknas. (2008). Kurikulum Tingkat Satuan Pendidikan. Jakarta: Depdiknas.

Hartati, Sofia. (2005). Perkembangan Belajar pada Anak Usia Dini. Jakarta: Depdiknas.

Kelley, Michael., Keith Wetzel., Helen Padgett., Mia Kim Williams., and Mary Odom. (2003). "Early Childhood Teacher Preparation and Technology Integration: The Arizona State University West Experience". Journal of Contemporary Issues in Technology and Teacher Education, Vol. 3 No. 1, 2003, pp: $\quad 67 \quad-63$, http://www.proquest.umi.com diakses 12 Januari 2012.

Krogh, Suzanne L., and Kristine L. Slentz. (2011). Early Childhood Education: Yesterday, Today, and Tomorrow. London: Routledge. 
Kusbudiah, Yayah. (2014). Pengelolaan Pembelajaran Di RA/TK/PAUD Sebagai Upaya Mengoptimalkan Pencapaian Perkembangananak Usia Dini. Diakses pada

http://bdkbandung.kemenag.go.id/jurnal/ 276-pengelolaan-pembelajaran-di-ra-tkpaud-sebagai-upaya-mengoptimalkanpencapaian-perkembangan-anak-usiadini tanggal 16 April 2017

Muhadjir, Noeng. (1996). Metodologi Penelitian Kualitatif. Edisi Ke-3. Yogyakarta: Rake. Sarasin.

Noorlaila. (2010). Panduan Lengkap Mengajar PAUD. Yogyakarta: Kelompok Penerbit Pinus.
Prapsiwi, Dwi. (2012). Pengelolaan Pembelajaran Pendidikan Anak Usia Dini (Studi Situs di TK Negeri Pembina Boyolali). Jurnal Program Studi Manajemen Pendidikan Program Pascasarjana Universitas Muhammadiyah Surakarta 2012.

UNESCO. (2007). Strong Foundations for Gender Equality in Early Childhood Care and Education-Advocacy Brief. UNESCO.

UU No. 20 Tahun 2003 tentang Sistem Pendidikan Nasional. 